\title{
New sights for Land
}

\section{Washington}

Dr Edwin H. Land, a legendary figure in US industrial history for his invention of the instant camera and for founding the Polaroid Corporation, announced on 27 July that he would resign as a director and chairman of the board of the company. When a remaining role as a consultant expires at the end of the year, Land will have relinquished all direct responsibility for the company identified with his name. Since 1975 , he has been gradually breaking his links with the corporation in order to devote himself to research on colour vision and related fields. He is now 73 .

\section{Freedom ideal}

As an inventor, however, Land has surprised no one in inventing an entirely new setting for his new career as a full-time scientist. Earlier this month, he gave me an exclusive tour of the Rowland Institute, a luxurious new building of brick, slate and oak that he has built and endowed on the banks of the Charles River in Cambridge, Massachusetts, only a few blocks from his old centre of operations at Polaroid.

At present, only 25 of the 80 people expected to work at the institute have been engaged, but Land is in no hurry to fill it up quickly, he explained, as he mounted, two steps at a time, a circular stairway carved in poplar wood leading to a large two-storey atrium housing a Japanese style garden and off which lay two storeys of eight doublelaboratories.

Land's favourite word to describe the idea of the institute is freedom. Here, he and colleagues will be free from the pressures of writing government funding proposals or the demands of industry - or, perhaps, the burden of running Polaroid, which has had its troubles in recent years. To ensure this freedom, Land has endowed the institute with $\$ 20$ million. "This is an experiment to see what will happen if a group of competent, intelligent and bright people were pursuing the substance of science itself for its own sake, without thought of product or profit", he says.

Some of the basic work to be undertaken, such as the study of lightinduced heat transfer across molecular surfaces, is not far from work done at Polaroid, which was famous for exploring the frontiers of the science that underlay its projects. "We were very proud of the basic work we did at Polaroid. But while we were doing it we carried a very different and very proud burden.

"It was a joy to make new films, new dyes and new cameras" said the holder of 533 patents, who is a member of the US Inventors Hall of Fame, along with Thomas Alva Edison and others. "It is a different kind of joy if the product is deep insight into natural phenomena from which there may be by-products internally". The institute, like any other non-profit group, will be eligible to apply for patents and to accept royalties. But, Land stresses, basic science will be the product, with any inventions that transpire the by-product - not the other way around. Perhaps the Rowland Institute is Polaroid in reverse.

The institute aims to be collegial in style, explains James Foley, an organic chemist from Polaroid whom Land hired nine months ago. "Each of us is a sun on our own project, with the others as satellites, and I will be a satellite on Jim's project" says Land. Projects at present contemplated range from Land's own work on the physics of colour vision to an examination of the structure of biologically important molecules.

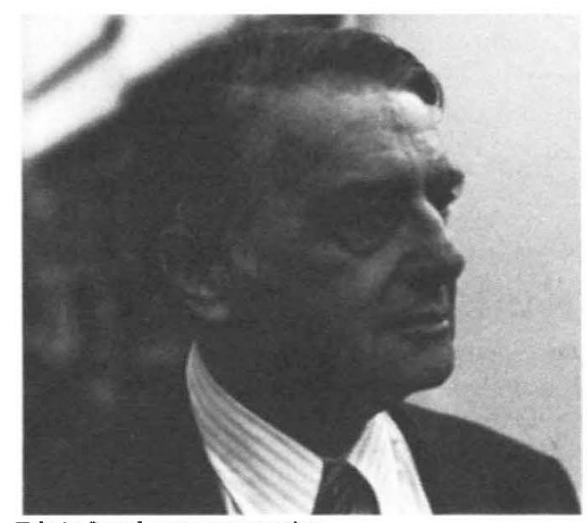

Edwin Land, new perspectives

For all its newness, its large, quiet library, Mexican grey pebbles and whisperperfect auditorium, the institute is avoiding stocking up on fancy equipment (although each scientist may have a computer terminal in his office). Nor is Land hiring "teams" of people to work on a single project. He is opposed to both as too likely to drag researchers away from pursuing a clear, logical line of enquiry. Once you have a big machine, he says, you tend to work on problems the machine can do, rather than those that are most important or interesting.

The enormous darkroom in the basement, for example, has only a few items in it. There, Land happily shows off a phenomenon he discovered only the day before, in which the eye, after exposure to a certain kind of light, sees the fan-shaped spokes on a wheel become narrower. "We're going to look at one thing, then the next, and the next, without trying to explain too much at first. In a sense, we're returning to an older style of doing science. This was how Faraday worked."'

\section{Base of success}

Back at Polaroid, the reins of power are now firmly in the hands of William $J$. McCune Jr who has been with the company since 1939, and whom Land made president in 1975, chief executive officer in 1980 , and who now becomes chairman of the board too. McCune, who is 67 , is an independent Polaroid power in his own right. One story has it that he recently rebuffed two would-be kidnappers in a local parking lot. Most discussions of Polaroid's health and future tend to show McCune and the board of directors seeing things differently from Land, although there is no indication of an outright break being the cause of Land's present departure.

Indeed, Polaroid, while highly successful with sales of $\$ 1,400$ million, has had several things to disagree about internally. The film manufacturers have been hard hit by the rising price of silver in the late 1970s. In addition, the amateur camera market, which accounts for 80 per cent of Polaroid's business, levelled in those years in response to the recession, at a time when Polaroid had doubled its camera and film-making capacity in what proved to be a mistaken expectation of continued growth. Both US sales and sales in Europe, which had grown spectacularly, tailed off. The company workforce, which numbered 20,000 in 1979 , now stands at approximately 15,000 , and a number of high executives have been offered generous terms to leave to reduce management too.

Finally, the company has gone on introducing the kind of spectacular, unique inventions for which Land was famous such as Time Zero film, an improvement on the SX-70 film first introduced in 1972. But it has also recently experienced its first real failure: Polavision, an instant movie camera and film system introduced in 1977 and withdrawn in 1979 . The system came just when video products were coming along, and cost more than a comparable video system; the company had to write off an estimated \$68 million and opinions vary over the extent to which Land bears the blame. McCune is seen as strongly favouring the company's decision, in recent years, to expand out of the volatile amateur camera market and into commerical, industrial and scientific products. Polaroid now offers cameras for computer graphics to industry and cameras for medical purposes, including nuclear medicine for example.

Will Polaroid go on being inventive after Land? He says "One of my functions was - innocently - to insulate the company from many of the conventional criteria by which companies are judged on a monthly or quarterly basis.

"If with my insulation removed, the company becomes susceptible to these judgements ... this will lead to a basic conflict between two different approaches: first, the long-term, imaginative approach of sensing an unmet human need and bringing it, by way of science, to fulfillment; and second, responding to a chorus of external contemporary voices." What will be Polaroid's next big invention? Land laughs, but won't say. "I hope they guess what I hope it will be", he replies.

Deborah Shapley 